\title{
GENE POLYMORPHISM OF TRANSFORMING GROWTH FACTOR BETA-1 (TGF-B1) AND ITS LEVEL IN RHEUMATOID ARTHRITIS PATIENTS ASSOCIATED WITH OSTEOPOROSIS DISEASE
}

\author{
Gina Ashraf Said ${ }^{a, b}$, Youssri Hussein*, Hoda El-Sayed ${ }^{a}$, Mervat Askar ${ }^{a}$ \\ ${ }^{a}$ Biochemistry Department, Faculty of Pharmacy, Zagazig University, Egypt \\ ${ }^{b}$ Biochemistry Department, Faculty of Pharmacy, MSA University, Egypt \\ *Medical Biochemistry Department, Faculty of Medicine, Zagazig University, Egypt
}

\begin{abstract}
Objective: The imbalance between pro-inflammatory and anti-inflammatory cytokines is a feature of rheumatoid arthritis (RA). The role of transforming growth factor beta-1 (TGF- $\beta 1$ ) and its receptor in the pathogenesis of RA is conflicting. We aim to investigate the role of polymorphisms in the gene in susceptibility and severity of RA and osteoporosis.

Methods: Eighty-six RA patients and eighty-four control were enrolled in the study.

Genotyping of TGF- $\beta 1$ T/C869 and TGF- $\beta 1$ G/A800 was determined by restriction fragment length polymorphismpolymerase chain reaction (PCR-RFLP).

Results: Subjects carrying T allele of TGF- $\beta 1$ T/C869 genotype were significantly more likely to have osteoporosis than subjects carrying C allele (OR:6.95, 95\% CI: 2.7-15.7, P: 0.001).Also, Subjects with A allele of TGF- $\beta 1$ G/A800 genotype were significantly more likely to have osteoporosis (OR: 1.13, 95\% CI: 1.05-1.2, P: 0.001).

Conclusion: T/C869 genotype and G/A800 genotype of TGF- $\beta 1$ gene affecting on severity of RA and have the ability to develop the risk to osteoporosis in patients carrying $\mathrm{T}$ allele and A allele of T/C869 and G/A800 gene polymorphism respectively
\end{abstract}

Keywords: Transforming growth factor beta-1 (TGF- $\beta 1)$, Rheumatoid arthritis, Polymorphism, Osteoporosis

\section{INTRODUCTION}

$\mathbf{R}$ heumatoid arthritis (RA) is one of the most common human systemic autoimmune diseases. It is characterized by synovial infiltrates and a progressive cell-mediated destruction of the joints, which results in substantial disability [1].

Evidence suggests that both genetic and environmental factors contribute to susceptibility to RA [2].RA is a complex heterogeneous chronic autoimmune disease, whereby both environmental and genetic factors contribute to the etiology and/or clinical severity that affect approximately $1 \%$ of the world's population, with significantly higher prevalence in women than in men (in a 3:1 ratio) [3].

A central feature of RA is a relative imbalance in pro-inflammatory and anti-inflammatory cytokines, cytokines play an important role in RA pathogenesis [4].

Analyses of the cytokine mRNA and proteins in the RA synovial tissue revealed that Tumor necrosis factor- $\propto($ TNF- $\propto)$, Interlukin-1 (IL-1), Interluekin-6 (IL-6), and Transforming growth factor- $\beta$ (TGF- $\beta$ ) were expressed at high levels in RA patients [5].

Transforming growth factor beta (TGF- $\beta$ ) is a member of a family of growth factors that regulate cellular proliferation, cellular differentiation, embryonic development, wound healing, and angiogenesis in a cell-specific manner [6].Virtually every cell in the body, including epithelial, endothelial, hematopoietic, neuronal, and connective-tissue cells, produces TGF- $\beta$ and has receptors for it. Elevation or decrease in the production of TGF $\beta$ has been lied to numerous disease states [7].

The human TGF- $\beta 1$ gene is located on chromosome $19 \mathrm{q} 13$ and contains seven exons [8].

Transforming growth factor beta 1 (TGF- $\beta 1$ ) is produced by osteoblasts as an inactive propeptide and is incorporated into newly formed bone matrix. During bone resorption, the propeptide is activated by the acid milieu in the resorptive zone under the osteoclast. TGF- $\beta 1$ inhibits further activity of the osteoclasts and stimulates proliferation and differentiation of preosteoblasts. The overall effect on bone remodeling of TGF- $\beta 1$ is therefore favoring bone formation [9].

Because of this important role in bone turnover, the TGF- $\beta 1$ gene is a candidate for mediating genetic influence on bone mass and risk of fracture [9].Among the genes that has been associated with change in Bone mineral density (BMD) is TGF beta 1 therefore, that the TGF- $\beta 1$ locus has emerged as a strong candidate gene in the study of osteoporosis genetics [10].

Several polymorphisms in TGF- $\beta 1$ gene have been reported. One polymorphism has been reported in promoter region at position G/A800 and the other in the coding sequence at T/C869 [8] and these restriction fragment length polymorphisms (RFLPs) are detected by the restriction endonucleases enzymes TSP 451 and MSP A11 respectively [11]. 
Polymorphic variations of the cytokine genes or their receptors have received attention as potential markers of susceptibility, severity, and/or protection in RA [12]. In the present study, we evaluated the role of two polymorphisms in the TGF- $\beta 1$ gene in RA susceptibility and severity.

Table 1

Clinical characteristics of patients group

\begin{tabular}{lc} 
Variables & $\begin{array}{c}\text { RA group } \\
(\mathbf{n = 8 6})\end{array}$ \\
\hline Age (yrs) & $47.5 \pm 9.4$ \\
\hline TGF(Transforming growth factor beta-1) & $35.8 \pm 16.5$ \\
\hline
\end{tabular}

Number of patients with erosions (\%)

$30(34.8)$

Number of patients with positive rheumatoid factor $(\%)$

$59(68.6)$

\section{Diagnosis}

Number of Normal patients (\%)

Number of Osteopenia patients (\%)

Number of Osteoporotic patients (\%)

$18(20.9)$

$38(44.2)$

$30(34.9)$
Patients were recruited from the outpatients and inpatients population of the Department of Rheumatology.

Subjects enrolled in the study underwent routine biochemical blood analysis. X-rays of the hands and feet were obtained in all patients. The evaluation of subjects included physical examination, with particular focus on the pattern of joint involvement, the presence of nodules and other extra-articular features (such as vasculitis, anemia, subcutaneous nodules, vasculitis manifestation, organ involvement), and laboratory features such as rheumatoid factor (RF). Disease activity was determined on the basis of defined parameters (The number of swollen and tender joints, ESR, and Creactive protein (CRP)) and a global physician's assessment.

Disease severity was determined on the basis of defined parameters (RF and X-ray erosion). Patients were deemed to have an erosive arthropathy if one or more definitive erosions were apparent in any of the peripheral joints that have been identified to be predictive of disease progression [14]. Patients were then stratified according to the radiographic findings into two groups: those with erosive RA and those with non-erosive RA.84 healthy women matched to age (30-62 years, mean $43.9 \pm 9.6)$, and ethnic origin were used as a healthy control group.

2.2. Biochemical analysis

Blood samples were drawn from all subjects after an overnight fast. Sera were separated immediately and stored at $-20 \circ$ C. Serum TGF- $\beta 1$ and CRP were measured using high-sensitivity enzyme-linked immunosorbent assay (ELISA) for TGF- $\beta 1$ and CRP respectively, developed in-house and performed in sandwich format [15]. IgM RF was measured by latex agglutination. RF was considered positive above $20 \mathrm{IU} / \mathrm{ml}$.

\subsubsection{Isolation of DNA}

Genomic DNA was extracted from EDTA whole blood using a spin column method according to the protocol (QIAamp Blood Kit; Qiagen GmbH, Hilden, Germany).

2.2.1.1. Amplification of two TGF- $\beta 1$ polymorphic sites

The subjects were genotyped for TGF- $\beta 1$ T/C869 and TGF- $\beta 1 \mathrm{G} / \mathrm{A} 800$ polymorphisms by PCR-RFLP as described previously $[8,11]$. For TGF- $\beta 1$ T/C869 polymorphism the region surrounding the polymorphism was amplified with following forward primers 5 ' TTCCCTCGAGGCCCTCCTA-3' and the reverse primer 5'- GCCGCAGCTTGGACAGGATC- 3'. 
PCR was performed at initial denaturation at $95{ }^{\circ} \mathrm{C}$ for $5 \mathrm{~min}$, followed by 35 cycles of denaturation at $95{ }^{\circ} \mathrm{C}$ for $1 \mathrm{~min}$, annealing at $60{ }^{\circ} \mathrm{C}$ for $1 \mathrm{~min}$, extension at $72{ }^{\circ} \mathrm{C}$ for $30 \mathrm{~s}$, and final extension at 72 ${ }^{\circ} \mathrm{C}$ for $12 \mathrm{~min}$. The PCR products for (T/C869) were digested at $37{ }^{\circ} \mathrm{C}$ overnight by restriction enzymes (MspA11). The MspA11 restriction polymorphism revealed two possible alleles, allele $\mathrm{C}$ and $\mathrm{T}$. The digestion products $(161,67,40$ and 26 bp for $\mathrm{T}$ allele and 149, 67, 40 and 12 bp for C allele). While for TGF- $\beta 1$ G/A800 polymorphism the region surrounding the polymorphism was amplified with following forward primers $5^{\prime}$ GTTGGCGAGAACAGTTGGC-3' and the reverse primer 5' -GAAAGGACAGAAGCGGTGC-3' .PCR was performed at initial denaturation at $94{ }^{\circ} \mathrm{C}$ for $5 \mathrm{~min}$, followed by 35 cycles of denaturation at $94{ }^{\circ} \mathrm{C}$ for $1 \mathrm{~min}$, annealing at $64{ }^{\circ} \mathrm{C}$ for $30 \mathrm{~s}$, extension at $72{ }^{\circ} \mathrm{C}$ for $1 \mathrm{~min}$, and then a final extension at $72{ }^{\circ} \mathrm{C}$ for $8 \mathrm{~min}$. The PCR products for TGF- $\beta 1$ were digested at $37{ }^{\circ} \mathrm{C}$ overnight by restriction enzymes (TSP 451). TSP 451 produces DNA fragments with fragment sizes 300/161 and139 bp as 1 band at $300 \mathrm{bp}$ in the abnormal homozygous GG. The heterozygous AG should appear as 3 bands at 300, 161, and 139 bp. The normal homozygous AA should appear as 2 bands at $161,139 \mathrm{bp}$. The digest products of both genotypes were analysed by electrophoresis on a 2.5\% agarose gel then stained with ethidium bromide and the genotypes were determined.

Table 2

Distribution of TGF- $\beta 1$ T/C869 and TGF- $\beta 1$ G/A800 genotypes in RA patients and control group

\begin{tabular}{|c|c|c|c|c|}
\hline & & $\begin{array}{c}\text { RA patients } \\
\mathrm{N}=86, \mathrm{~N} \\
(\%)\end{array}$ & $\begin{array}{c}\text { Control } \\
\mathrm{N}=\mathbf{8 4}, \mathbf{N}(\%)\end{array}$ & $\boldsymbol{P}$ \\
\hline \multirow[t]{2}{*}{ T/C869 genotype } & $\begin{array}{l}\text { CC } \\
\text { TC } \\
\text { TT }\end{array}$ & $\begin{array}{l}12(21.4) \\
35(42.9) \\
39(35.7)\end{array}$ & $\begin{array}{l}18(21.4) \\
36(42.9) \\
30(35.7)\end{array}$ & 0.3 \\
\hline & $\begin{array}{l}\text { C Allele } \\
\text { T Allele }\end{array}$ & $\begin{array}{c}59(34.3) \\
113(65.7)\end{array}$ & $\begin{array}{l}72(42.9) \\
96(57.1)\end{array}$ & 0.13 \\
\hline \multirow[t]{2}{*}{ G/A800 genotype } & $\begin{array}{l}\text { AA } \\
\text { GA } \\
\text { GG }\end{array}$ & $\begin{array}{c}2(2.3) \\
8(9.3) \\
76(88.4)\end{array}$ & $\begin{array}{c}0(0.0) \\
12(14.3) \\
72(85.7)\end{array}$ & 0.2 \\
\hline & $\begin{array}{l}\text { G Allele } \\
\text { A Allele }\end{array}$ & $\begin{array}{c}160(93.1) \\
12(6.9)\end{array}$ & $\begin{array}{c}156(92.9) \\
12(7.1)\end{array}$ & 0.87 \\
\hline
\end{tabular}

$P$ value of $>0.05$ indicates non-significant results

$* \mathrm{P}$ value of $<0.05$ indicates a significant results

TGF- $\beta 1$ : Transforming growth factor- $\beta 1$, RA: rheumatoid arthritis

\subsubsection{Statistical analysis}

The results for continuous variables were expressed as means \pm SD. The means of the three genotype groups were compared in a one- way analysis of variance (ANOVA). Genotype frequencies in RA cases and control were tested for Hardy-Weinberg equilibrium, and any deviation between the observed and expected frequencies was tested for significance using Chi-square test. The statistical significance of differences in frequencies of variants between groups were tested using Chisquare test. In addition, the odds ratio (ORs) and 95\% Confidence interval (CIs) were calculated as a measure of the two polymorphic sites of TGF- $\beta 1$ with RA and osteoporosis. A difference was considered significant at $P<0.05$. All data were evaluated using SPSS version 10.0 of Windows.

\section{RESULTS}

3.1 TGF- $\beta 1$ polymorphisms genotypes and alleles distribution in RA and control

The genotypes frequencies of TGF- $\beta 1$ T/C 869 and TGF- $\beta 1$ G/A800 were in agreement with Hardy-Weinberg equilibrium in all groups. In RA patients, the frequencies of TGF- $\beta 1 \mathrm{~T} / \mathrm{C} 869$ and TGF- $\beta 1$ G/A800 genotypes were not significantly different compared to control group respectively. Also,the allele frequencies of both genotypes weren't significantly differenet between control and patients group (Table 2). 
3.2 Association of TGF- $\beta 1$ (T/C869 and G/A800) genotypes with osteoporosis

In RA patients with osteoporosis, the frequencies of TT genotypes of TGF- $\beta 1$ T/C869 were significantly increased compared to patients without osteoporosis $(76.7 \%$ versus $28.6 \%)$. The frequencies of GG genotype of TGF- $\beta 1$ G/A800 were significantly increased in RA patients with osteoporosis compared with RA patients without osteoporosis (100\% versus $82.1 \%$ ) (Table 3 ).

Subjects with $\mathrm{T}$ allele of TGF- $\beta 1 \mathrm{~T} / \mathrm{C} 869$ genotype were significantly more likely to develop osteoporosis $(\mathrm{OR}=6.95,95 \% \mathrm{CI}=2.7-15.7, \quad P$ $=0.001)$. And for TGF- $\beta 1$ G/A800 genotype, subjects with $\mathrm{G}$ allele were significantly more likely to develop osteoporosis $(\mathrm{OR}=1.13,95 \% \mathrm{CI}=1.05$ $1.2, P=0.003$ ) (Table 4).

Table 3

Association of TGF-ß1 (T/C869 and G/A800) genotypes with osteoporosis in rheumatoid arthritis patients

\begin{tabular}{|c|c|c|c|c|}
\hline \multirow{2}{*}{ Genotype } & \multicolumn{2}{|c|}{$\begin{array}{c}\text { RA with osteoporosis } \\
\qquad \mathbf{N}=\mathbf{3 0}\end{array}$} & \multicolumn{2}{|c|}{$\begin{array}{l}\text { RA without osteoporosis } \\
\qquad \mathrm{N}=56\end{array}$} \\
\hline & $\mathbf{N}$ & $\%$ & $\mathbf{N}$ & $\%$ \\
\hline $\mathbf{C C}$ & 0 & 0.0 & 12 & 21.4 \\
\hline TC & 7 & 23.3 & 28 & 50.0 \\
\hline TT & 23 & 76.7 & 16 & 28.6 \\
\hline \multicolumn{3}{|c|}{$\mathbf{X 2}$} & \multicolumn{2}{|c|}{19.81} \\
\hline \multicolumn{3}{|c|}{$P$} & \multicolumn{2}{|c|}{$0.001 *$} \\
\hline $\mathbf{A A}$ & 0 & 0.00 & 2 & 3.6 \\
\hline AG & 0 & 0.00 & 8 & 14.3 \\
\hline GG & 30 & 100.0 & 46 & 82.1 \\
\hline \multicolumn{3}{|c|}{$\mathrm{X} 2$} & \multicolumn{2}{|c|}{6.06} \\
\hline \multicolumn{3}{|c|}{$P$} & \multicolumn{2}{|c|}{$0.048^{*}$} \\
\hline
\end{tabular}

$P$ value of $>0.05$ indicates non-significant results

$* \mathrm{P}$ value of $<0.05$ indicates a significant results

TGF- $\beta 1$ : Transforming growth factor- $\beta 1$, RA: rheumatoid arthritis

Table 4

Association of TGF-ß1 (T/C869 and G/A800) allele with osteoporosis in rheumatoid arthritis patients

\begin{tabular}{|c|c|c|c|c|}
\hline \multirow{2}{*}{ Alleles } & \multicolumn{2}{|c|}{ RA with OP } & \multicolumn{2}{|c|}{ RA without OP } \\
\hline & $\mathbf{N}$ & $\%$ & $\mathbf{N}$ & $\%$ \\
\hline C allele & 7 & 11.7 & 52 & 46.4 \\
\hline $\mathrm{T}$ allele & 53 & 88.3 & 60 & 53.6 \\
\hline $\mathrm{X}^{2}$ & & & \multicolumn{2}{|c|}{19.28} \\
\hline$P$ & & & \multicolumn{2}{|c|}{$0.001^{*}$} \\
\hline OR $(95 \% \mathrm{CI})$ & & & \multicolumn{2}{|c|}{$6.95(2.7-15.7)$} \\
\hline G allele & 60 & 100 & 100 & 89.3 \\
\hline A allele & 0 & 0.0 & 12 & 10.7 \\
\hline $\mathbf{X}^{2}$ & & & \multicolumn{2}{|c|}{7.47} \\
\hline$P$ & & & \multicolumn{2}{|c|}{$0.003^{*}$} \\
\hline OR (95\% CI) & & & \multicolumn{2}{|c|}{$1.13(1.05-1.2)$} \\
\hline
\end{tabular}

$\mathrm{P}$ value of $>0.05$ indicates non-significant results

$* \mathrm{P}$ value of $<0.05$ indicates a significant results

OD: Odds ratio, CI: Confidence interval, TGF- $\beta 1$ : Transforming growth factor- $\beta 1$, RA: rheumatoid arthritis 


\section{DISCUSSION}

Rheumatoid arthritis (RA) is a common, chronic, inflammatory, autoimmune disease of unknown etiology affecting approximately $1 \%$ of the world population. The hallmark swelling, bony erosions and synovial thickening reflect the underlying inflammatory and autoimmune processes. The interaction of environmental factors and genetic susceptibility leads to altered posttranscriptional regulation and self-protein citrullination early in the disease process [16].

The role of genetic factors in the pathogenesis of RA is well established. Numerous cytokines which are expressed and functionally active in synovial tissues are directly implicated in many of the immune processes that are associated with the pathogenesis of RA [17].

Transforming growth factor TGF- $\beta 1$ is a multifunctional cytokine that regulates cell growth, adhesion, and differentiation in a wide variety of cell types. Among the activities of TGF- $\beta 1$ are those associated with growth modulation, immunosuppression, and pro-inflammation. TGF- $\beta 1$ is produced in the synovial fluid of patients with RA and acts as an important regulator in the course of the disease. TGF- $\beta 1$ was reported to increase the expression of pro-inflammatory cytokines and metalloproteinase- 1 by synovial fibroblasts .These results suggest that TGF- $\beta 1$ contributes to the progression of inflammation and joint destruction in RA [18].

Transforming growth factor (TGF) $\beta 1$ (TGF- $\beta 1$; $19 q 13.1)$ was one of the first suggested candidate genes to contribute to genetic risk for osteoporosis for several reasons. TGF $\beta 1$ is expressed by osteoblasts, is present in high concentrations in bone tissue and involved in the control of bone resorption and formation [19].

The present study had analyzed two selected single nucleotide polymorphisms (SNPs) of the TGF- $\beta 1$ gene one in the promoter region G/A800 and the other located in the codon at position T/C869 in RA patients and healthy controls and their relationship to markers of synovial inflammation as susceptible factors for development of osteoporosis and rheumatoid arthritis.

The higher prevalence of autoimmunity in women suggests that sex hormones might play a role in susceptibility. Estrogen is thought to exert a biphasic dose effect lower levels enhance while high levels inhibit specific immune activities whereas progesterone promotes the development of T-helper2 (Th2) cells which inhibits the proliferation of the T-helper1 (Th1) cells [20]. Pregnancy is associated with a marked increase of estrogen, progesterone and cortisol in the plasma and brings about remission in autoimmune disorders such as RA and multiple sclerosis which are both driven by Th1 cytokines [21].

In our study regarding the level of TGF- $\beta 1$ showed to be raised in plasma level of RA patients which indicate its effect on incidence of RA.

These results are in agreement with Alayli et al. , kim et al. ,Mattey et al. , Mieliauskaite et al. ,Rico et al. ,Hinke et al. , and Arkwright et al. $[6,11,22-26]$

TGF- $\beta 1$ is one of the cytokines which exerts both pro- and anti-inflammatory effects. TGF- $\beta 1$ mediates an array of biologic processes, including growth and development, inflammation, and host defense, as well as tissue repair TGF- $\beta 1$ is generated by inflammatory cells as part of the cytokine network. In its defensive role, TGF- $\beta 1$ facilitates resolution of inflammation and promotes tissue repair. However, as for the cytokine network, a critical balance of this growth factor is required for its defensive properties to take place in an orchestrated fashion.

The literature indicates that a local or systemic excess of this growth factor is associated with unresolved inflammation; indeed, TGF- $\beta 1$ plasma levels are increased in RA patients and constitutively up-regulated in RA synoviocytes [24].

These observations are in agreement with the current study, and they represent an opportunity to explore the interface of the cytokine network of TGF- $\beta 1$.

In the present study, TGF- $\beta 1$ gene polymorphism of T/C869 genotype reveled nonsignificant difference in genotype either allele compared with that of healthy controls and RA patients. Reports on the association of this gene polymorphism with RA have been inconsistent.

This may be due to ethnic population studied since Suguira et al. ,Wang YP et al. and Zhu Y et al. [27-29] reported that TGF- $\beta 1$ T/C869 T allele was related to RA whereas Pokorny et al.[30], Alayli et al. [6] and Panoulas et al. [31] didn't observe any relation.

Our results are consistent with Pokorny et al. , Alayli et al. and Panoulas et al. [30,6,31].

Conflicting results have been reported regarding the influence of T/C869 genotype polymorphism on TGF- $\beta 1$ production. In the present study the $\mathrm{T}$ allele 
of T/C869 gene polymorphism is associated with higher production of TGF- $\beta 1$.

These results in agreement with Alayli et al. , Hinke et al. and Arkwright et al. [6,25,26]

But that was in converse with Yamada $Y$ et al. [32] and Mattey et al. [22] as their results suggest that rheumatoid patients carrying a $\mathrm{T}$ allele may have increased inflammatory activity over the long term. The poor outcome and earlier mortality in these patients may possibly be explained by reduced production of TGF- $\beta 1$ leading to worse control of inflammation. Such an effect would be cumulative so may only become evident in long term outcome studies.

In the present study, subjects carrying $\mathrm{T}$ allele of T/C 869 genotype have 6.9 folds increase the risk to develop osteoporosis than subjects carrying $\mathrm{C}$ allele.

These results in agreement with Yamada Y et al. [32] and Dick et al. [33]. An association with osteoporosis has been found in Japanese women Yamada $Y$ et al.[32] and in elderly white Australian women Dick et al. [33]. However, in the Japanese population the $\mathrm{T}$ allele was associated with lower bone mineral density (BMD) and increased vertebral fractures, while in the Australian patients the $\mathrm{C}$ allele was associated with lower $\mathrm{BMD}$ and an increase in prevalent fractures. In another study of German postmenopausal women the CC genotype was associated with lower BMD and greater bone loss [25].

In contrast to these reports, studies in a Chinese population, and on white women in the USA, failed to find an association lau et al. and Ziv et al. [34-35] respectively. Also, studies in postmenopausal Turkish women found that TGF- $\beta 1$ gene not associated with development of osteoporosis in single form but found in association in combined form with Interleukin-10 (IL-10) [19]. While Mattey et al.[22] found no association of T/C869 TGF- $\beta 1$ gene polymorphism with the severity of RA. Since patients were examined only up to two years of disease duration, so it is possible that the effect of this polymorphism becomes evident at a later stage of disease.

In the Japanese population the $\mathrm{CC}$ genotype was associated with elevated serum TGF- $\beta 1$ concentration [32], and the German population the TT genotype was associated with elevated serum TGF- $\beta 1$ concentration [25]. This may be due to ethnic differences in the population studied. The association of TGF- $\beta 1$ T/C869 polymorphism observed with increase bone turnover rate and fragility fractures is compatible with the proposed mechanism of TGF- $\beta 1$, which is believed to be a mediator of coupling between bone resorption and formation [34].

However the present study demonstrated that the difference in serum TGF- $\beta 1$ concentration with TT genotype indicating the association of TGF- $\beta 1$ T/C869 with ability to develop the risk with osteoporosis.

The current study showed that TGF- $\beta 1$ G/A800 gene polymorphism and revealed no significant difference either genotype or allele in RA patients with healthy control which explained that G/A800 genotype not gene of risk of RA.

These results are in agreement with Tzakas et al.[10] ,Cambien et al.[36] and Jeffrizal et al. [37] and who examined French, Irish and UK populations.

On the other hand Kim et al. [11] show low frequency in G/A800 genotype in the Asian Korean population which reflects the difference in genotype distribution among study populations with a distinct racial background.

Early identification of reliable predictors of severity of the disease is important as the erosions are correlated with clinical outcome, such as disability [38-39]. Moreover, O'Dell reported that early treatment may retard bone destruction [40]. Therefore, the potential to early predict the individual who will require more aggressive treatment would be especially valuable.

The present study demonstrated an increase in the risk to develop osteoporosis in subjects carrying $\mathrm{G}$ allele by 1.13 folds than subjects with $\mathrm{G}$ allele.

The association of $\mathrm{G}$ allele with bone erosions in RA patients suggests the potential role of these polymorphisms to be used as a predictive marker. In fact, the estimated predictive value of TGF- $\beta 1$ G/A800 the polymorphism revealed the powerful capacity of the $G$ allele to identify individuals with a high risk of early bone erosion. Identification of patients homozygous for the $G$ allele permitted the prediction of a rapidly erosive disease course.

\section{Disclosure of interest}

This work was funded by support of academic research in Zagazig University Projects, Zagazig University Postgraduate \& Research Affairs.

\section{CONCLUSION}

T/C869 genotype and G/A800 genotype of TGF- $\beta 1$ gene affecting on severity of RA and have the ability to develop the risk to osteoporosis in patients carrying $\mathrm{T}$ allele and A allele of T/C869 and G/A800 gene polymorphism respectively. 


\section{REFERENCES}

1) Firestein GS (2003) "Evolving concepts of rheumatoid arthritis". Nature;423:356-61.

2) Deighton CM, Walker DJ (1991) "The familial nature of rheumatoid arthritis". Ann Rheum Dis ;50:62-5.

3) MacGregor AJ, Snieder H, Rigby AS, et al (2000) "Characterizing the quantitative genetic contribution to rheumatoid arthritis using data from twins". Arthritis Rheum;43:30-7.

4) John S, Myerscough A, Marlow A, et al (1998) “ Linkage of cytokine genes to rheumatoid arthritis. Evidence of genetic heterogeneity". Ann Rheum Dis;57:361-5.

5) Cheon H, Yu SJ, Yoo DH, et al (2002) "Increased expression of pro-inflammatory cytokines and metalloproteinase-1 by TGF-beta1 in synovial fibroblasts from rheumatoid arthritis and normal individuals". Clinical and experimental immunology; 127:547-552.

6) Alayli G, Kara N, Tander B, et al (2009) "Association of transforming growth factor $\beta 1$ gene polymorphism with rheumatoid arthritis in a Turkish population”. Joint Bone Spine; 76:20-23.

7) Makhdom AM, Hamdy RC (2013) "The Role of Growth Factors on Acceleration of Bone Regeneration during Distraction Osteogenesis". Tissue engineering Part B, Reviews.

8) D. Amani, S. Farjadian, Ghaderi A (2008) "The frequency of transforming growth factor- $\beta 1$ gene polymorphisms in a normal southern Iranian population". Blackwell Publishing Ltd, International Journal of Immunogenetics;35:145151.

9) Bente Lomholt Langdahl, Mette Carstens, Liselotte Stenkjær, Eriksen EF (2003) "Polymorphisms in the transforming growth factor beta 1 gene and osteoporosis". Bone; 32:297-310.

10) Tzakas P, Wong BY, Logan AG, et al (2005) "Transforming growth factor beta-1 (TGFB1) and peak bone mass: association between intragenic polymorphisms and quantitative ultrasound of the heel". BMC musculoskeletal disorders;6:29-10.

11) Kim S, Han S, Kim G, et al (2004) "TGF- $\beta 1$ polymorphism determines the progression of joint damage in rheumatoid arthritis". Scandinavian Journal Of Rheumatology;33:389-394.

12) Lee DM, Weinblatt ME (2001) "Rheumatoid arthritis". Lancet;358:903-11.

13) Arnett FC, Edworthy SM, Bloch DA, et al (1988) "The American Rheumatism Association 1987 revised criteria for the classification of rheumatoid arthritis". Arthritis Rheum;31:315-24.

14) Sharp JT (2000) "An overview of radiographic analysis of joint damage in rheumatoid arthritis and its use in metaanalysis". J Rheumatol;27:254-60.

15) Eda S, Kaufmann J, RoosW, et al (1998) "Development of anewmicroparticle-enhanced turbidimetric assay for C-reactive protein with superior features in analytical sensitivity and dynamic range". J Clin Lab Anal;12:137-44.

16) Gibofsky A (2012) "Overview of Epidemiology, Pathophysiology, and Diagnosis of Rheumatoid Arthritis". American Journal of Managed Care;18:S295-S302.

17) Karlson EW, Ding B, Keenan BT, et al (2013) "Association of environmental and genetic factors and gene-environment interactions with risk of developing rheumatoid arthritis". Arthritis care \& research.

18) Cho ML, Min SY, Chang SH, et al (2006) "Transforming growth factor beta 1(TGF-beta1) down-regulates TNFalpha-induced RANTES production in rheumatoid synovial fibroblasts through NF-kappaB-mediated transcriptional repression". Immunology letters;105:159-166.

19) Tural S, Alayli G, Kara N, et al (2013) “Association between osteoporosis and polymorphisms of the IL10 and TGF-beta genes in Turkish postmenopausal women". Human immunology.

20) Hussein Y, El-Tarhouny S, Mohamed R, et al (2012) "Association of interleukin-4 receptor gene polymorphisms with rheumatoid arthritis in Egyptian female patients". Joint Bone Spine;79:3842.

21) Al-Shammri S, Rawoot P, Azizieh F, et al (2004) "Th1/Th2 cytokine patterns and clinical profiles during and after pregnancy in women with multiple sclerosis". Journal of the neurological sciences;222:21-27.

22) Mattey DL, Nixon N, Dawes PT, Kerr J (2005) "Association of polymorphism in the transforming growth factor \{beta\}1 gene with disease outcome and mortality in rheumatoid arthritis". Annals of the rheumatic diseases;64:1190-1194.

23) Mieliauskaite D, Venalis $P$, Dumalakiene I, et al (2009) "Relationship between serum levels of TGF$\beta 1$ and clinical parameters in patients with rheumatoid arthritis and Sjogren's syndrome secondary to rheumatoid arthritis". Autoimmunity;42:356-358.

24) Rico MC, Manns JM, Driban JB, et al (2008) "Thrombospondin-1 and transforming growth factor beta are pro-inflammatory molecules in rheumatoid arthritis". Translational Research;152:95-98.

25) Hinke V, Seck T, Clanget C, et al (2001) "Association of transforming growth factor-beta1 (TGFbeta1) T29 --> C gene polymorphism with bone mineral density (BMD), changes in BMD, and serum concentrations of TGF-beta1 in a populationbased sample of postmenopausal german women". Calcified tissue international;69:315-320.

26) Arkwright PD, Laurie S, Super M, et al (2000) "TGF-beta(1) genotype and accelerated decline in lung function of patients with cystic fibrosis". Thorax;55:459-462. 
27) Sugiura $Y$, Niimi $T$, Sato $S$, et al (2002): "Transforming growth factor betal gene polymorphism in rheumatoid arthritis". Annals of the rheumatic diseases;61:826-828.

28) Wang YP, Xiao LS, Zhou Y, et al (2007) "Gene polymorphisms of transforming growth factor-b1 with rheumatoid arthritis". Chin J Public Health;11:1405-1406

29) Zhu Y, Liu F, Zhang F, et al (2006) "Correlation of transforming growth factor-b1 T869C polymorphism and rheumatoid arthritis in Chinese population". Jiangsu Med J;32:1112-1114.

30) Pokorny V, Chau J, Wu L, et al (2003) "Transforming growth factor beta 1 gene (HSTGFB1) nucleotide T869C (codon 10) polymorphism is not associated with prevalence or severity of rheumatoid arthritis in a Caucasian population". Annals of the rheumatic diseases;62:907-908

31) Panoulas VF, Douglas KM, Smith JP, et al (2009) "Transforming growth factor-beta1 $869 \mathrm{~T} / \mathrm{C}$, but not interleukin-6 -174G/C, polymorphism associates with hypertension in rheumatoid arthritis". Rheumatology (Oxford, England);48:113-118.

32) Yamada Y, Miyauchi A, Goto J, et al (1998) "Association of a polymorphism of the transforming growth factor-betal gene with genetic susceptibility to osteoporosis in postmenopausal Japanese women". Journal of bone and mineral research : the official journal of the American Society for Bone and Mineral Research;13:1569-1576.

33) Dick IM, Devine A, Li S, et al (2003) "The T869C TGF beta polymorphism is associated with fracture, bone mineral density, and calcaneal quantitative ultrasound in elderly women". Bone;33:335-341

34) Lau EM, Wong SY, Li M, et al (2004) "Osteoporosis and transforming growth factor-beta1 gene polymorphism in Chinese men and women". Journal of bone and mineral metabolism;22:148-152

35) Ziv E, Kahn A, Cauley J, et al (2003) "No association between the TGF-beta 1 Leu10Pro polymorphism and osteoporosis among white women in the United States". The American journal of medicine; 114:227-231

36) Cambien F, Ricard S, Troesch A,et al (1996) "Polymorphisms of the transforming growth factorbeta 1 gene in relation to myocardial infarction and blood pressure. The Etude Cas-Temoin de l'Infarctus du Myocarde (ECTIM) Study". Hypertension;28:881-887

37) Jeffrizal MFRFB, Said MSBM, Radzi ABTM, et al (2009) "Profile of Transforming Growth Factor Beta 1 Gene (TGF- b1) Nucleotide 29 T869C Polymorphism in Malaysian Rheumatoid Arthritis patients". Internet Journal of Rheumatology;6:1-1

38) Yazici Y, Pincus T, Kautiainen H, Sokka T (2004) "Morning stiffness in patients with early rheumatoid arthritis is associated more strongly with functional disability than with joint swelling and erythrocyte sedimentation rate". The Journal of rheumatology;31:1723-1726.

39) Kirwan JR (2001) "Links between radiological change, disability, and pathology in rheumatoid arthritis". The Journal of rheumatology;28:881-886.

40) O'Dell JR (2002) "Treating rheumatoid arthritis early: a window of opportunity?" Arthritis and rheumatism;46:283-285 